\title{
Dékor of konteks? - Die verdiskontering van sosio-historiese gegewens in interpretasie van 'n Nuwe Testament-teks vir die prediking en pastoraat, geillustreer aan die hand van die 1 Petrus-brief
}

F Janse van Rensburg (Potchefstroomse Universiteit vir Christelike Hoër Onderwys)

\section{ABSTRACT}

Decor or context? The utilisation of socio-historic data in the interpretation of a New Testament text for the preaching and pastorate, illustrated with First Peter

The article proposes, from a reformed perspective, a method for the valid utilisation of the socio-historic data of a New Testament book in the process of interpretation. Firstly a synoptic indication of the difference between a "background" and a "context" approach is given, as well as of a socio-historic and the socio-scientific approach, and of an emic and an etic approach, in each case motivating the choice for a specific approach. The sources for the determination of the sociohistoric context of the New Testament are indicated, and the preference for literary sources motivated. The theological perspective from which the utilisation is done, is defined, specifically the relation between the Bible text and other sources, in the light of Articles 2-7 of the Belgic Confession. The preferred view of text and society is given, as well as the reasons for the preference in each case. All of this is done, using First Peter as illustration.

\section{INLEIDING}

\subsection{Oriëntering en probleemstelling}

Die Nuwe Testament het ontstaan in, en dra die tekens van, ander kulturele en sosiale omstandighede as in die byna een en twintigste eeuse Suid-Afrika. ' $n$ Mens kan eers die krag van Nuwe-Testamentiese woorde en begrippe begin verstaan, as daar vasgestel is wat hulle waarskynlik in die tyd van die ontstaan van die betrokke dokument beteken het (Van Unnik 1980:203). 'n Geldige konstruksie van die waarskynlike sosiohistoriese konteks moet dus gemaak word.

Die data wat nodig is vir die konstruering van hierdie sosiohistoriese konteks, is geredelik beskikbaar. Die verdiskontering daarvan in die interpretasieproses lewer egter etlike teoretiese en praktiese probleme op.

- Enersyds was daar vir byna ' $n$ eeu die neiging om hierdie data te sien as bloot die "kultuur-historiese agtergrond" van die Nuwe 
Testament, wat niks meer is as die (dooie) "dékor" van die dinamiese gebeure wat in die Nuwe Testament beskryf is nie.

- Andersyds is daar weer dikwels die neiging om tot ' $n$ ander uiterste op te gaan. Elliott (1981:21) stel byvoorbeeld dat elke Nuwe-Testamentiese boek "like all documents of the early Christian movement, is a product of and a contribution toward a social world in the making".

- " $n$ Derde probleem kom by: die wyse waarop in die interpretasieproses met die sosio-historiese gegewens van die eerste eeu omgegaan word, het beslissende implikasies vir die wyse waarop die sosiale en politieke gegewens van die huidige tyd in die toepassing van die boodskap vir vandag verreken word.

Die spesifieke probleem wat ondersoek word, is hoe sosio-historiese gegewens van ' $n$ Nuwe-Testamentiese boek in die interpretasieproses deur ' $n$ Gereformeerde Nuwe-Testamentikus en ' $n$ bedienaar van die Woord in die reformatoriese tradisie verreken kan word.

Om hierdie probleem op te los, word die volgende teoretiese vrae beantwoord, en ten opsigte van 1 Petrus (veral 2:11-12) geïllustreer:

- Wat is die verskil tussen " $n$ "agtergrond"- en ' $n$ "konteks"-benadering, en die gronde vir voorkeur van die konteksbenadering?

- Wat is die verskil tussen die sosio-historiese en die sosio-wetenskaplike benadering, en die gronde vir voorkeur van die sosiohistoriese benadering?

- Wat is die verskil tussen ' $n$ emiese en " $n$ "etic" benadering, en die gronde vir voorkeur van ' $n$ emiese benadering?

- Wat is die aard van die bronne vir die bepaling van die buite-tekstuele konteks van 'n Nuwe-Testamentiese boek, en waarom is daar voorkeur vir die literêre bronne?

- Vanuit watter teologiese perspektief word die verdiskontering gedoen? En spesifiek: wat is die verhouding tussen die Bybelteks en ander bronne?

- Vir watter teksbeskouing is daar voorkeur, en waarom?

- Vir watter samelewingsbeskouing is daar voorkeur, en waarom?

- Wat is die beginsels vir die interpretasie van 'n Bybelboek vir die sosiale en politieke konteks van vandag?

\subsection{Doelstelling}

Die doelstelling is om, op ' $n$ wyse wat ook vir die bedienaar van die Woord bevatlik en relevant is, aan te toon hoe die sosio-historiese gegewens van ' $n$ Nuwe-Testamentiese boek in die interpretasieproses geldig op grond van reformatoriese vertrekpunte verreken kan word. 


\subsection{Sentrale teoretiese argument}

Die "konteks"-benadering is ' $n$ meer geldige en effektiewe manier om met die sosio-historiese gegewens van die Nuwe Testament om te gaan, as wat die agtergrondbenadering dit is.

\subsection{Metodologie}

Hierdie Nuwe-Testamentiese sosio-historiese navorsingstudie word gedoen vanuit die gereformeerde tradisie.

In die oorsigtelike aantoning van die genoemde teoretiese aspekte, en die grond vir die voorkeur telkens, word die stand van navorsing op grond van literatuurstudie bepaal.

Waar tersaaklik, word die eksegese volgens die grammaties-historiese metode (Deist \& Burden, 1980:111-113) gedoen, en woord-studie volgens die metode van komponensiële analise, met die ontginning van die data van die Louw \& Nida-woordeboek (1989).

\section{PETRUS 2:11-12}

Ter wille van gemaklike latere verwysing word die teks van 1 Petrus 2:11-12 volledig gegee:

\begin{tabular}{|c|c|}
\hline Griekse te & se Vertaling ${ }^{1}$ \\
\hline 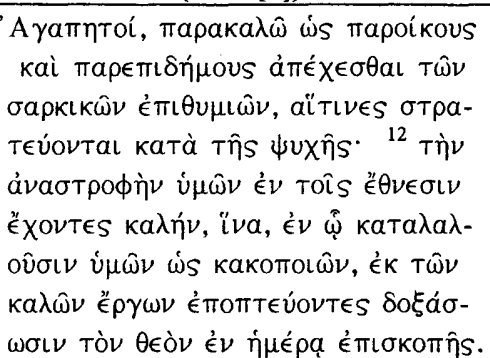 & $\begin{array}{l}\text { Geliefdes, ek dring by julle as vreemdelinge } \\
\text { en bywoners daarop aan om nie aan julle } \\
\text { natuurlike geaardheid toe te gee nie. Dit } \\
\text { verwoes net 'n mens se lewe. }{ }^{12} \text { Gedra julle } \\
\text { altyd goed onder die heidene sodat, al praat } \\
\text { hulle kwaad van julle asof julle misdadigers } \\
\text { is, hulle julle voorbeeldige lewe kan sien, en } \\
\text { God kan verheerlik op die dag van } \\
\text { afrekening. }\end{array}$ \\
\hline
\end{tabular}

\section{HOOFPUNTINDELING}

Die behandelingsorde is die volgende:

1 Die verskil tussen " $n$ "agtergrond" en "n "konteks"-benadering;

2 Die verskil tussen die sosio-historiese en die sosio-wetenskaplike benadering;

3 Die verskil tussen ' $n$ emiese en ' $n$ etiese benadering;

4 Die aard van die bronne vir die konstruksie van die buite-tekstuele konteks van 'n Nuwe-Testamentiese boek;

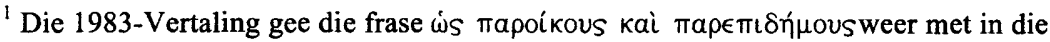
wêreld is julle vreemdelinge en bywoners. Die toevoeging van in die wêreld gee daaraan noodwendig 'n figuurlik-geestelike betekenis. Daarom word in die eie vertaling die frase in die wêreld weggelaat. 
5 Die teologiese perspektief;

6 Die teksbeskouing;

7 Die samelewingsbeskouing;

8 Interpretasie vir die sosiale en politieke konteks van vandag;

9 Samevatting;

10 Implikasie vir die onderrig en navorsing.

\subsection{Die verskil tussen 'n "agtergrond"- en 'n "konteks"-benade- ring}

Die agtergrondbenadering en konteksbenadering werk met dieselfde buite-tekstuele gewens: die sosiale en politieke omstandighede van die tydvak waarin die betrokke boek ontstaan het. Die verskil lê egter in die wyse waarop daardie gegewens by die verstaan van die betrokke boek verdiskonteer word ${ }^{2}$.

' $n$ Mens kan maklik hare kloof oor terme, en te veel daaruit aflei. Wanneer iemand egter na die sosiale en politieke gegewens met betrekking tot die Nuwe Testament verwys as die "kultuurhistoriese agtergrond van die Nuwe Testament", is dit gewoonlik tekenend daarvan dat sodanige persoon hierdie gewens (ten minste in die praktyk van interpretasie) as dooie agtergrond hanteer, soos die dékor in 'n teater.

Volgens hierdie benadering gee ' $n$ Nuwe-Testamentiese boek die aksie op die verhoog weer, en die sosiale en politieke gegewens is die dooie dékor. Daar is geen werklike interaksie tussen die gebeure op die verhoog en die dékor nie. Die dékor gee wel 'n bietjie reliëf, maar die enigste dinamika is onder die karakters in die opvoering. Hierdie karakters verwys wel na die "agtergrond", na dinge in die dékor, maar daardie dékor bly dood.

Die sosio-historiese gegewens word nie regtig in die interpretasieproses verdiskonteer nie, maar word bloot as agtergrondsketsing gebruik. Vergelyk Duvenage (s j) se boek met die titel Die dékor van die Nuwe Testament. 'n Kultuur-historiese agtergrondstudie.

Hierteenoor is die konteksbenadering meer soos 'n film oor dieselfde gebeure. Die sosiale en politieke omstandighede is nou nie meer dooie props op die "verhoog" nie, maar déél van die dinamiese gebeure op die "verhoog".

- Waar die agtergrond van 'n Bybelboek die backdrop van die boek aandui, dui die konteks van die boek presies aan wat die woord konteks beteken: die gebeure in die boek word beskou as verweefd met die sosiale en politieke werklikhede van dáárdie era. Die

\footnotetext{
${ }^{2}$ Een van die goeie dinge wat die strukturalisme veroorsaak het, is dat daar " $n$ nuwe waardering vir die "verweefdheid", nie net van taalverskynsels nie, maar van alles in die werklikheid, gekom het.
} 
Christene word gesien as deel van 'n dinamiese samelewing; ook as groep is die Christene met hierdie samelewing in interaksie.

- Waar by die agtergrondbenadering die boek geïnterpreteer word teen die agtergrond van die sosiale en politieke gegewens, interpreteer die konteksbenadering die boek binne die konteks van die hierdie gegewens, of nog duideliker gesê: in terme van hierdie gegewens.

- Waar daar by die agtergrondbenadering in die interpretasiepraktyk 'n isolasie is van die gebeure ín die boek, beskou die konteksbenadering die gebeure in die boek as geintegreerd deel van die volledige buite-tekstuele konteks van die boek.

Die agtergrondbenadering bestudeer dus wel die politieke en sosiale gegewens, maar as 'n saak op sigself, en die effek daarvan blyk op ten minste twee maniere:

- In die akademiese kurrikulum word die vak "kultuur-historiese agtergrond" 'n geïsoleerde appendiks: die student kry die opdrag om deur die loop van die betrokke semester ' $n$ bron (of meer) oor die kultuur-historiese agtergrond deur te werk, en dan word dit as 'n losstaande saak geëvalueer, om niks meer vas te stel as die student se feite-kennis oor hierdie kultuurhistoriese agtergrond nie. Binne die konteksbenadering eindig dit nie hier nie. Ná die feitekennis kom die eintlike saak aan die orde: om raak te sien hoe die betrokke Bybelboek sou kon inpas binne 'n konstruksie van die leefwêreld van die tyd van sy ontstaan, en: watter effek dit het op die interpretasie van onderdele van die boek.

- In kommentare wat vanuit die agtergrondbenadering geskryf is, word die kultuur-historiese agtergrond van die boek netso geïsoleerd aangebied. Dit maak deel uit van die inleidingstof van die boek, en later in die boek word op 'n lukraak manier selde van daardie inligting verreken. In kommentare vanuit die konteksbenadering word 'n konstruksie van die sosio-historiese konteks gemaak. Die hele boek word dan binne daardie konstruksie geïnterpreteer $^{3}$.

${ }^{3}$ Die waarskynlike "texture of life" (Meeks 1983:2) in die gebied(e) waar die geadresseerdes geleef het, word hiervolgens bepaal, en dan word die tersaaklike data verreken in die verstaan van die betrokke boek. 


\subsection{Toegepas op 1 Petrus:}

\begin{tabular}{|c|c|}
\hline 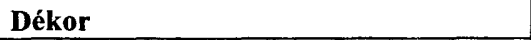 & \\
\hline $\begin{array}{l}\text { roenewald (1977:7-11) gee in sy } \\
\text { leiding inligting oor die historiese } \\
\text { tuasie wat deur die brief aangedui } \\
\text { ord. Behalwe om te meld dat die } \\
\text { eadresseerdes verspreid gewoon en } \\
\text { lein gemeenskappe gevorm het, en dat } \\
\text { ie meerderheid van hulle dalk slawe } \\
\text { as, gee hy geen verdere aanduiding van } \\
\text { ulle sosiale en politieke omstandighede } \\
\text { ie. } \\
\text { Vanneer hy later (1977:43) sy } \\
\text { ommentaar op } 2: 11-12 \text { gee, is daar geen } \\
\text { errekening van wat hy in sy inleiding } \\
\text { or die historiese situasie gesê het nie. } \\
\text { y interpretasie van die terme bywoners } \\
n \text { vreemdelinge is dan ook volledig } \\
\text { guurlik-geestelik: Dit beteken dat die } \\
\text { elowiges hulle wel in die wêreld bevind } \\
n \text { hier moet lewe, maar met die leefwyse }\end{array}$ & $\begin{array}{l}\text { Isburg (1993:1946) gee by sy } \\
\text { g van 1:1-2 'n konstruksie van } \\
\text {-tekstuele konteks van } 1 \text { Petrus. } \\
\text { onder andere dat die vreemde- } \\
\text { van die eerste lesers hulle } \\
\text { status kan aandui: dat hulle as } \\
\text { s geen burgerregte het in die } \\
\text { vaar hulle woon nie. Hulle het } \\
\text { blyfreg. } \\
\text { hy later (1993:1950) sy } \\
\text { taar op } 2: 11-12 \text { gee, verreken hy } \\
\text { wat hy aanvanklik oor die sosio- } \\
\text { konteks gesê het. Hy } \\
\text { lik wat die status van uitlanders } \\
\text { was (o.a. dat hulle nie eiendom } \\
\text { nie, en die prooi van veronreg- } \\
\text { iskriminasie was), en hoe hierdie } \\
\text { ting verdiep het wanneer so 'n } \\
\text { Christen word. Hy wys ook hoe } \\
\text { wer hierdie skeld-terme tot 'n } \\
\text { mvorm (1993:1951). }\end{array}$ \\
\hline
\end{tabular}

Soos later hieronder (punt 9) sal blyk, maak hierdie verrekening van die sosiale en politieke omstandighede van die eerste hoorders/lesers dit moontlik om die boodskap van hierdie kort perikopie baie spesifieker toe te pas vir gelowiges vandag, en om nie in algemene geestelike waarhede verskuild te raak nie.

\subsection{Die verskil tussen die sosio-historiese en die sosio- wetenskaplike benadering}

Die sosio-wetenskaplike benadering ${ }^{4}$ en die sosio-historiese benadering werk met dieselfde buite-tekstuele gegewens: die sosiale en politieke omstandighede van die tydvak waarin die betrokke boek ontstaan het. Die verskil lê egter in die metodes wat gebruik word om daardie gegewens by die konstruksie van die buite-tekstuele konteks van die betrokke Bybelboek te verreken.

Vanuit 'n sekere hoek bekyk vorm die suiwer sosio-wetenskaplike benadering en die suiwer sosio-historiese benadering die twee uiterste pole van 'n kontinuum. Elke persoon wat navorsing doen oor die sosio-

\footnotetext{
${ }^{4}$ Die sosiaal-wetenskaplike benadering is ook vroeër getipeer as die sosiologiese benadering (Vgl Botha 1990:58-62).
} 
historiese konteks van 'n Bybelboek, bevind hom/haar êrens op hierdie kontinuum: óf neigend nader aan die suiwer sosio-wetenskaplike, of nader aan die suiwer sosio-historiese. Die volgende bied 'n oorsigtelike tipering van hierdie twee pole ${ }^{5}$ :

- By die sosiaal-wetenskaplike benadering funksioneer die uitgangspunte van die sosiaal-wetenskaplike dissiplines as vertrekpunte, terwyl die sosio-historiese benadering teologies bly, wel met die gebruikmaking van resultate van die sosiaal-wetenskaplike dissiplines.

- Die sosiaal-wetenskaplike benadering is sosiologies, terwyl die sosio-historiese benadering sosiaal is. Dit hou onder andere in dat, in die konstruksie van die sosio-historiese konteks van die betrokke Bybelboek, die sosiaal-wetenskaplike benadering op sosiologiese teorieë (daargestel op grond van navorsing van huidige sosiale verskynsels) konsentreer, terwyl die sosio-historiese benadering op die sosiale verskynsels van die eerste eeu konsentreer ${ }^{6}$.

Die belowendste benadering is $(\mathrm{m}$ i) die sosio-historiese benadering. Dit word verryk deur die vrae wat sosiaal-wetenskaplikes vra en die resultate van die modelle wat hulle gebruik ${ }^{7}$.

- Die "suiwer" sosio-historiese metode gaan mank daaraan dat die beoefenaar in teorie-vergetelheid verkeer: daar word op 'n intuïtiefnaïewe wyse met die sosiale gegewens gewerk, asof dit moontlik is om teorievry te werk. Intussen word nie teorievry gewerk nie, maar met ' $n$ intuïtiewe en naïewe teorie, ongedefinieer en ongetoets.

- Die "suiwer" sosiaal-wetenskaplike metode gaan weer daaraan mank dat die beoefenaar se fokus eensydig ingestel is op temporêre teorieë en modelle, en dat die gegewens uit die tydvak van die betrokke boek sekondêr hanteer word.

Daarom die voorkeur vir 'n sosiaal-wetenskaplik verrykte sosio-historiese benadering.

\footnotetext{
${ }^{5}$ Vergelyk Botha (1990:58-62) vir 'n goeie vergelyking van die sosio-historiese en die sosio-wetenskaplike benadering, asook Garrett (1992).

${ }^{6}$ Vergelyk Botha (1990:58-62) en Elliott (1981:7) vir 'n vollediger bespreking van die onderskeid sosiaal en sosiologies.

${ }^{7}$ Hiermee bevind ek my onder die groep navorsers wat Garrett (1992:90), nadat sy die uiterste pole van die sosio-historiese en sosio-wetenskaplike benaderings beskryf het, soos volg tipeer: “... many have held that the most promising approach is one that continues to employ old methods and questions, but that is also informed by the questions social scientists ask and the models they employ."
} 


\subsection{Die verskil tussen ' $n$ emiese en ' $n$ etiese benadering}

Die onderskeiding emies/eties (emic/etic) is vanuit die linguistiek ${ }^{8}$ ook op die terrein van die sosio-historiese navorsing van toepassing gemaak.

- 'n Emiese benadering laat die klem val op die situasie van destyds. Data en verskynsels word beskryf in terme van die funksies binne die destydse samelewing. Die data en verskynsels dikteer as 't ware die ondersoek.

- ' $n$ Etiese benadering wil ook die situasie van destyds bestudeer, maar dan in terme van teorieë en modelle wat in die huidige tyd ontwikkel is op grond van data en verskynsels in huidige samelewings. Die ondersoek word gedikteer deur die betrokke teorie/ model.

Uit hierdie beskrywing is dit duidelik dat die sosiaal-wetenskaplike benadering wesenlik eties is, en die sosio-historiese wesenlik emies. My eie voorkeur is dus vir ' $n$ emiese benadering, ' $n$ poging om deurdrenk te raak met die data en verskynsels uit die era van die betrokke boek, sonder om met 'n vooropgesette teorie of model die data en verskynsels te bekyk $^{9}$.

\section{DIE AARD VAN DIE BRONNE VIR DIE KONSTRUKSIE VAN DIE BUITE-TEKSTUELE KONTEKS VAN 'N NUWE- TESTAMENTIESE BOEK}

Die hoofbronne vir die sosiale konstruksie van die vroeë Christendom is literêr (Malherbe 1983:15). Insigte uit argeologiese data word dus, soos die geval is met moderne sosiologiese teorieë, as sekondêr hanteer.

In hierdie verband is dit belangrik om in gedagte te hou dat daar in sekere opsigte ' $n$ groot verskil is tussen die vlak van die literêre kultuur soos blyk uit die Nuwe-Testamentiese boeke en dié van baie van die geskrifte kontemporêr aan die Nuwe Testament. Die Nuwe-Testamentiese geskrifte is byvoorbeeld van ' $n$ meer populêre aard, terwyl meeste van die ander geskrifte meer literêr en filosofies is. Tog lewer hierdie geskrifte waardevolle inligting vir die konstruksie van die buite-tekstuele

\footnotetext{
${ }^{8}$ Vir 'n definisie van die emic/etic-onderskeiding in die linguistiek, vergelyk Crystal (1985:108).

${ }^{9}$ Dit wil nie sê dat hier beredeneer word dat ' $\mathrm{n}$ emiese benadering nie teoriebepaald is nie. Wat die argument wel inhou, is dat die emiese benadering die data met betrekking tot die buite-tekstuele konteks van die boek nie met (en: in terme van) 'n sosiologiese model benader nie. Geen benadering is immers teorievry nie, en daarom is dit noodsaaklik dat elke navorser sy/haar interpretasieteorie eksplisiet maak. Sodoende word die effek daarvan op die navorsingsresultaat meetbaar en kontroleerbaar.
} 
konteks van 'n Bybelboek. Kategoride geskrifte wat vir hierdie doel ontginbaar is, is die volgende (vgl Malherbe 1983:19-20):

- Die papiri;

- geskrifte uit die kring van en oor die siniese filosowe;

- outeurs soos Dio Chrisostomos;

- die satiriste.

MacMullen (1981:206) beklemtoon tereg dat dit belangrik is om eerstehands met die ander, dit wil sê nie-Christelike bronne, te werk. Dit is belangrik om te weet wat nie-Christene geglo en gedink het, want "to ignore the prior views of converts or to depict the mission as operating on a clean slate is bound to strike an historian as very odd indeed."

Daar is ongelukkig geen bronne van nie-Christene uit die eerste eeu waarin hulle hulle siening van Christene uiteensit nie (vgl Malherbe $1983: 21)^{10}$. In die konstruksie van die sosio-historiese konteks moet dus rekening gehou word daarmee dat daar hoofsaaklik vier kategorieë getuienis is:

- Direkte verwysings in die Nuwe-Testamentiese boeke na die sosiale omstandighede;

- Opmerkings in die Nuwe-Testamentiese boeke waaruit bepaalde afleidings oor die sosiale omstandighede gemaak kan word;

- Direkte verwysings in ander literêre bronne oor die tersaaklike sosiale omstandighede;

- Opmerkings in die ander literêre bronne waaruit afleidings oor die tersaaklike sosiale omstandighede gemaak kan word.

Die werkmetode hou dus in dat inligting uit die betrokke Bybelboek gebruik word en gekorreleer word met historiese en sosiale data, en omgekeerd. Die oogmerk van dit alles is 'n geldige konstruksie van die buite-tekstuele konteks van die betrokke boek, in terme waarvan die interpretasie van die boek of perikoop dan gedoen kan word.

Hierdie werkmetode klop met wat in NGB Art 6 bely word. Alhoewel artikel 6 dit het oor die gebruik van apokriewe boeke, kan die beginsel wat gestel word van toepassing gemaak word op enige antieke bronne wat gebruik word. In artikel 6 word die apokriewe boeke gelys. Daar staan:

10 Wilken (1984:xiv-xv) noem dat die vroegste behoue vermelding van die Christendom deur 'n nie-Christelike skrywer tagtig jaar na die ontstaan van die Christendom plaasgevind het. Dit is ' $n$ ernstige leemte, en moet doelbewus in die konstruksie van die sosio-historiese konteks verreken word. 
"Die kerk mag hierdie boeke wel lees en daaruit lering trek vir sover hulle met die kanonieke boeke ooreenstem. Hulle het egter geensins sodanige krag of gesag dat iemand deur hulle getuienis enigiets van die geloof of van die Christelike godsiens sou kan bevestig nie. Hulle mag nie in die minste aan die gesag van die ander, die heilige boeke, afbreuk doen nie".

Om literêre bronne (apokriewe, pseudepigrawe of enige ander antieke bron) te gebruik om die buite-tekstuele konteks van 'n Bybelboek te konstrueer, is dus nie in stryd met hierdie belydenisskrif nie.

\subsection{Toegepas op 1 Petrus:}

Daar is noodwendig 'n voortdurende wisselwerking tussen besigwees met die teks van 1 Petrus, en die ander bronne. Besigwees met die teks van 1 Petrus gaan voorop ${ }^{11}$, want hierdie teks bevat betroubare getuienis oor die probleme wat die eerste hoorders/lesers in hulle interaksie met die nie-Christelike samelewing waarvan hulle noodwendig deel uitmaak, ondervind het (Elliott 1986:67; Malherbe 1983:17-18). Die teks gee aanduidings van die buite-tekstuele konteks, dit is die situasie van die geadresseerdes. Eers nadat die buite-tekstuele konteks op hierdie wyse met redelike sekerheid bepaal is, kan die studie sy volgende fase betree, naamlik die bepaling en bestudering van ander bronne wat lig op die buite-tekstuele konteks kan werp ${ }^{12}$.

Daar is egter die hele tyd 'n wisselwerking en 'n korrektief: resul-tate van die besigwees met die teks van 1 Petrus kan op nuwe fasette van die situasie dui, en omgekeerd: resultate van die bestudering van die situasie (uit ander bronne) kan lei tot ' $n$ ander en (hopelik) geldiger lesing van die teks van 1 Petrus.

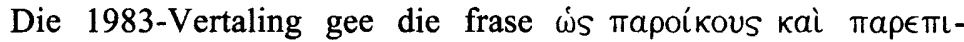

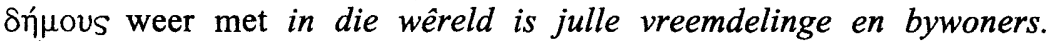
Reeds 'n oppervlakkige besigwees met die teks 1:11-12 laat dit duidelik word dat die frase in die wêreld 'n bepaalde kleur aan die twee Griekse woorde gee wat dit nie noodwendig moet hê nie. Nadat die gebruik van die terme in nie-Bybelbronne uit die eerste eeu bestudeer is, het dit duidelik geword dat die terme nie net in die LXX tegniese terme was om die Joodse bannelinge se vreemdelingstatus aan te dui nie, maar dat dit ook in die eerste eeuse Hellenistiese wêreld terme is wat spesifiek die politieke status van besoekende en gevestigde uitlanders aangedui het. In

${ }^{11}$ Malherbe (1983:17) beklemtoon tereg dat die Nuwe-Testamentiese geskrifte in sodanige studie voorrang moet geniet: "We must begin with these writings, and we must read them with a sensitivity to their social dimensions before we hasten to draw larger patterns."

${ }^{12}$ Die volgende artikels gee blyke van my eie interaksie met die teks van 1 Petrus: Van Rensburg 1990, 1990b, 1992 en 1992b. 
stand is hulle laer as die burgers van die betrokke staat, maar wel hoër as die slawe ${ }^{13}$.

Nadat hierdie inligting vanuit die nie-Bybelbronne verkry is, is die definisies getoets aan 1 Petrus (en ander Nuwe-Testamentiese boeke). Daar is bevind dat dit die verstaan van die boek toespits en verdiep. ${ }^{14}$

\section{TEOLOGIESE PERSPEKTIEF VAN WAARUIT DIE VERDISKONTE-RING GEDOEN WORD}

Geen interpretasie kan vooronderstellingloos gedoen word nie. In plaas daarvan om die bestaan van vooronderstellings te ontken, of op objektiewe verklaring te roem, moet die eie teologiese tradisie duidelik vermeld word. Verder moet daar ook 'n teoretiese en praktiese aanduiding wees van die implikasies van hierdie teologiese perspektief.

My eie teologiese perspektief is dat elke Bybelboek deel uitmaak van die bundel boeke, die Ou en Nuwe Testament, wat kanonies en daarom gesagvol is vir die gelowige se verhouding met God en sy naaste (vgl NGB, Art 2-7). Die betrokke Bybelboek is veel meer as net die produk van of 'n bydrae tot 'n wordende sosiale wêreld. 'n "Vertikale faktor" is by die ontstaan van hierdie boeke betrokke, naamlik God Drie-enig. Hy gebruik onder andere die sosiale omstandighede om nuwe fasette van die openbaring van sy wil tot uitdrukking te laat kom, om só vir die geslagte daarna - en dus ook vir ons - gedragskodes vir meerdere konkrete situasies daar te stel, en te wys hoe geopenbaarde beginsels in verskillende sosiale en politieke situasies toegepas moet word.

\subsection{Toegepas op 1 Petrus:}

Elliott (1981:21) stel byvoorbeeld dat 1 Petrus "like all documents of the early Christian movement, is a product of and a contribution toward a social world in the making".

Vanweë my eie teologiese perspektief kan ek hierdie uitgangspunt nie onderskryf nie. Dit is wel so dat die Nuwe-Testamentiese boeke getuienis gee van die dinamiese sosiale wisselwerking tussen persone wat op gegewe tye op spesifieke plekke geleef het (vgl Garrett 1992:90). Om dié boeke egter te beskryf as die produk van sosiale prosesse, is om God se direkte, vormgewende en inisiatief-nemende betrokkenheid daarby te ontken. My teologiese perspektief maak dat daar juis erkenning vir sodanige betrokkenheid van God is.

Hierdie erkenning veroorsaak dat die opdrag in 1 Petrus 2:11-12 nie maar net beskou word as 'n mens (Petrus) se advies vir sy eerste hoorders/lesers nie, maar as God se opdrag vir die uitlander-Christene

${ }^{13}$ Vgl Van Wyk \& Van Rensburg (1997:237-240) vir 'n vollediger bespreking van die uitlanderverskynsel in die eerste eeu.

$14 \mathrm{Vgl} \mathrm{Van} \mathrm{Rensburg} \mathrm{(1992b:283-306)} \mathrm{vir} \mathrm{'n} \mathrm{voorlopige} \mathrm{definiëring} \mathrm{van} \mathrm{die}$ betekenisse van die betrokke Griekse woorde. 
oor hoe hulle moet reageer op die veronregting en diskriminasie waaronder hulle ly: hulle moenie aan hulle natuurlike geaardheid toegee en terug kwaad doen nie, maar die kwaad wat hulle aangedoen word, met goed-doen neutraliseer.

Die erkenning het ook 'n verdere implikasie: God se opdrag geld ook vir Christene in Suid-Afrika vandag. Wanneer hulle sou ly onder politieke veronregting en diskriminasie, mag hulle nie aan hulle natuurlike geaardheid toegee en terug kwaad doen nie!

\section{TEKSBESKOUING}

Dit is belangrik dat die navorser uitspel wat sy/haar teksbeskouing is, en ook prakties en teoreties die implikasie van daardie beskouing verreken.

Die teksbeskouing op grond waarvan sosio-historiese gegewens in die interpretasie van 'n Nuwe-Testamentiese teks vanuit die teologiese perspektief hierbo (punt 6) uiteengesit, verdiskonteer kan word, is die volgende:

Die teks van 'n dokument is nie 'n blote outonome artefak wat selfreferensieel en dus outosemanties is nie. Aan die ander kant is die teks ook nie 'n blote tekensisteem wat deur die leser geaktiveer moet word nie.

- Indien die artefak-standpunt gehandhaaf sou word, lê daar 'n weerspreking in die oogmerk met die studie. As ' $n$ mens immers net belangstel in die teks en wat die teks sê (en ook glo dat die teks self alles sê, en dat dit bloot op grond van die teks self bepaalbaar is), sou die bestudering van die buite-tekstuele konteks van 'n boek nie ter sake wees nie. Dit sou voldoende wees om bloot net met die teks van die betrokke boek te werk.

- Aan die ander kant, indien die tekensisteem-beskouing gehandhaaf sou word, bots dit weer met die teologiese uitgangspunt dat God met die teks 'n bepaalde boodskap kommunikeer, sowel destyds aan die eerste hoorders/lesers, as vandag aan die huidige hoorders/ lesers. Volgens die tekensisteem-standpunt ken die leser betekenis aan die teks toe, en dra die teks nie self daardie betekenis nie.

Die uitgangspunt is dat die teks self wel betekenis het, en dat dit die verantwoordelikheid van die leser is om deur die gebruikmaking van geldige wetenskaplike metodes en met die duidelike uitspel van sy/haar vooronderstellings, daarna te streef om die boodskap van die teks te formuleer. Noodwendig - vanweë die gebrokenheid van die mens - bly dit in ' $n$ sekere sin 'n strewe en realiseer dit nooit volledig nie. Tog kan 
daar ontwikkeling wees; die blote feit dat dit moontlik is om oor die "stand van navorsing" te handel, laat dit blyk.

Hierdie teksbeskouing het dus komponente van sowel die artefakstandpunt as die tekensisteem-standpunt; dit is in ' $n$ sekere sin 'n kombinasie daarvan, daarin dat die teks gesien word as ' $n$ kommunikasie-handeling.

\subsection{Toegepas op 1 Petrus:}

Sekere van die praktiese implikasies van hierdie teksbeskouing is die volgende: die teks van 1 Petrus en die ander primêre bronne word onder andere soos 'n venster gebruik waardeur mens uitkyk om 'n indruk te vorm van die tersaaklike fasette van die sosiale wêreld van destyds. Die "indruk" wat ek as leser "kry", máák ek eintlik, maar nie op bloot intuïtiewe en subjektiwistiese wyse nie. Dit is ' $n$ ingeligte indruk, medebepaal deur eie vooronderstellings. Daarom moet dit so duidelik as moontlik uitgespel word.

Die teks van 1 Petrus word gebruik om die oogmerk wat die outeur gehad het, uit die brief te konstrueer: Om Christene wat deur die samelewing veronreg word, te bemoedig en riglyne te gee om op 'n Christelike wyse op daardie veronregting te reageer (Van Rensburg 1993: 1944). Ook hier is dit noodwendig die navorser se konstruksie, en daarom is dit en bly dit - soos alle wetenskaplike arbeid - voorlopig en relatief. Die navorser moet juis moeite doen om die pad wat geloop word om by die konstruksie uit te kom, so duidelik as moontlik uit te spel, sodat dit gekontroleer en die geldigheid daarvan só bepaal kan word.

\section{DIE SAMELEWINGSBESKOUING}

Enige konstruksie van die buite-tekstuele konteks van 'n Bybelboek, kan nie net op stelle data gebaseer word nie, maar ook op konsepsies van hoe hierdie data onderling met mekaar verband hou. Daarom is dit noodsaaklik dat die sosiale teorie waarmee die data geïnterpreteer word, uitgespel word, sodat die navorser se interpretasie van die data teen die agtergrond van en met verwysing na sy samelewingsbeskouing geëvalueer kan word $^{15}$. Die model help om die data te organiseer sodat suksesvol veralgemeen kan word. Alhoewel die oogmerk juis is om nie sosiaal-wetenskaplik te werk te gaan nie, en ook nie in die eerste plek om op grond van die data te veralgemeen nie, is dit tog belangrik dat uitgespel word binne watter raamwerk data ontgin en geïnterpreteer word.

\footnotetext{
15 Elliott (1986:78) beklemtoon byvoorbeeld tereg dat (re)konstruksie van sosiale situasies en die konseptualisering van sosiale dinamikas wat in antieke tekste geïmpliseer is, net gedoen kan word wanneer geldige sosiaal-wetenskaplike modelle gebruik word.
} 
Een van die noodsaaklike toetse vir 'n goeie model is dat dit al die tersaaklike data huisves. Verder moet dit nie voorskriftelik wees nie (Balch 1986:79; Meeks 1983:5).

In navolging van Meeks (1983:6) word die samelewing beskou as 'n proses waarbinne persoonlike identiteit en sosiale vorme wedersyds en voortdurend deur interaksie (wat deur middel van simbole plaasvind) geskep word. Ook godsdiens is ' $n$ integrale deel van die kultuurnetwerk.

'n Verdere uitgangspunt, anders as by Meeks, is dat die Christelike godsdiens nie bloot ' $n$ sosiale verskynsel is nie; daar is ' $n$ vertikale dimensie by, naamlik daarin dat Gód die inisiatief neem, en dat Hy sy wil deur middel van die geskrifte wat die kerke mettertyd as kanoniese geskrifte erken het, bekend maak. Die feit dat hierdie vertikale dimensie nie (sosio-histories) bestudeer kan word nie, neem nie weg dat die veronderstelling van die bestaan daarvan 'n groot effek het, veral op die wyse waarop data in die teks van die Nuwe-Testamentiese boeke hanteer word, asook data uit ander bronne. Dit is noodsaaklik om hierdie effek, waar dit ter sake is, eksplisiet te maak.

\section{INTERPRETASIE VIR DIE SOSIALE EN POLITIEKE KONTEKS VAN VANDAG}

Die teks van die Bybelboek word ondersoek, nie bloot net om vas te stel wat die teks (na die leser se oortuiging) sê nie, maar ook wat die teks (en deur die teks die Heilige Gees) dóén, sowel met betrekking tot die eerste hoorders/lesers destyds, as met betrekking tot huidige Christene in SuidAfrika.

Dit is egter eers wanneer die sosiale en politieke omstandighede van die betrokke Bybelboek geldig gekonstrueer is, dat dit moontlik word om skerp en akkuraat te bepaal watter tipe sosiale en politieke situasies vandag deur die betrokke perikoop "belig" word.

Wanneer die boodskap van die Bybelboek (of perikoop) vir die gelowiges van vandag geïnterpreteer word, word hierdie proses grondliggend bepaal deur die prediker as interpreteerder en toepasser. Predikers se eie persoonlikheid, algemene en wetenskaplike agtergrond, teologiese tradisie, lewens- en wêreldbeskouing, die sosiaal-politiese situasie waarin hulle verkeer en die wyse waarop hulle dit beleef, die belewing van hulle persoonlike verhouding met God, dit wil sê, hoe hulle oor God se betrokkenheid by die kommunikasie van die teks teoretiseer, en hoe hulle daardie betrokkenheid self beleef. Dit alles bepaal die interpretasieproses.

Voorts bepaal die leser se visie op sý geadresseerdes se situasie grootliks hoe hy die toepaslikheid van die boodskap van die betrokke Bybelboek (of perikoop) op gelowiges vandag in Suid-Afrika sien. 
Dit beteken dat die prediker sy biddende interpretasie slegs tot voltooiing kan bring as hy sy eie tersaaklike sosiale en politieke konteks (en dié van sý waarskynlike hoorders) goed ken. Hy kan die huidige situasie eintlik net regtig ken, as hy goeie insig het nie net in die huidige stand nie, maar ook hoe die huidige stand histories tot verwerkliking gekom het.

Hiervoor is dit belangrik dat hy die wêreld waarin hy leef regtig moet ken, en dat hy die leefwêreld van die mense wat hy moet bedien, ook regtig ken.

Die eie sosiale en politieke omstandighede moet egter nie net sommer in die algemeen ontleed word nie. Die betrokke perikoop voorsien as't ware die kragtige soeklig wat spesifieke fasette van die huidige konteks in die kalklig gaan bring. Die betrokke perikoop skryf dus voor watter tipe sake in die huidige konteks aan die orde is.

\subsection{Toegepas op 1 Petrus 2:11-12}

Die prediker kan in die ontleding van sy/haar konteks die volgende selfondersoekende vrae stel, en biddend vasstel of sy/haar reaksie daarop werklik getipeer kan word as "nie aan my natuurlike geaardheid toegee nie" (2:11):

- Tot watter mate beleef ek self "vreemdelingskap" in my konteks, sowel in die sosiaal-politieke sin van die woord, as in die figuurlik-geestelike sin? Hoe beleef ek die politieke bedeling waarin Suid-Afrika nou is?

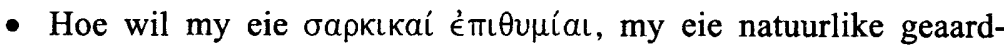
heid, reageer wanneer ek ly onder veronregting en diskriminasie?

- Watter getuienis kan ek uit my eie lewe gee oor hoe dit mens se lewe verwoes as jy toegee aan jou natuurlike geaardheid, en kwaad téén jou met kwaad vergeld?

- In watter opsigte bevind ek my onder "heidene", en in watter opsig praat hulle kwaad van my asof ek ' $n$ misdadiger is? (Dink ook spesifiek aan jou doen en late tydens die vorige politieke bedeling, meer spesifiek die feit dat alle optredes en motiewe in die "apartheidsera" afgemaak word as " $n$ sonde teen die mensdom".)

- Watter dinge is daar nou in my lewe waaroor die "heidene" my verguis, maar waaroor ek dink hulle God sal verheerlik op die dag van afrekening?

Die prediker moet ook die omstandighede van sy/haar waarskynlike hoorders verreken, en veral ook hoe hulle hulle omstandighede beleef (ongeag die geldigheid van daardie belewing). Baie Christene (juis blankes, en veral Afrikaanssprekendes) voel hulleself uitlanders en 
bywoners in hulle eie land. Hulle voel dat daar teen hulle gediskrimineer word, en dat misdadige motiewe en dade aan hulle toegedig word.

Die prediker moet die hoorders daarin begelei om te besef dat dit menslik is om terug "lelik" te wil wees wanneer mense teen hulle diskrimineer en hulle veronreg. Die prediker moet konkrete voorbeelde uit die onmiddellike samelewing noem om te wys dat vergelding (terug kwaad doen) beteken dat mens aan jou natuurlike geaardheid toegee, en dat dit uiteindelik in " $n$ spiraal van geweld ontwikkel wat alles verwoes".

\section{GEVOLGTREKKING}

Die sosio-historiese konteks van ' $n$ Nuwe-Testamentiese boek kan effektief deur 'n Gereformeerde Nuwe-Testamentikus en ' $n$ bedienaar van die Woord in die reformatoriese tradisie in die interpretasieproses verreken word wanneer daar biddend gepoog word om aan die volgende voorwaardes te voldoen:

- Wanneer die konteksbenadering (en nie die agtergrondbenadering) nie, die sosio-historiese benadering (en nie die sosio-wetenskaplike benadering), en ' $n$ emiese benadering (en nie ' $n$ etiese benadering) nie, gevolg word.

- Wanneer sowel die boeke van die Bybel as buite-Bybelse literêre bronne vir die bepaling van die buite-tekstuele konteks van 'n Nuwe-Testamentiese boek gebruik word, en inligting uit nieliterêre bronne ook sekondêr verreken word.

- Wanneer die Gereformeerde teologiese perspektief nie net bely word nie, maar bewustelik in die interpretasieproses verreken word.

- Wanneer die teks gesien word as ' $n$ kommunikasie-handeling, dit wil sê tegelyk 'n artefak én 'n tekensisteem.

- Wanneer die samelewing (van destyds en vandag) gesien word as as ' $n$ proses waarbinne persoonlike identiteit en sosiale vorme wedersyds en voortdurend deur interaksie (wat deur middel van simbole plaasvind) geskep word, met godsdiens as ' $n$ integrale deel van die kultuurnetwerk.

- Wanneer die sosiale en politieke omstandighede van die betrokke Bybelboek geldig gekonstrueer is, en skerp en akkuraat bepaal is

\footnotetext{
${ }^{16}$ As hierdie interpretasie vir die Suid-Afrikaanse sosiale en politieke situasie vergelyk word met dié van Groenewald (1977:43), blyk dit hoe spesifiek en "skerp" die toepassing word. Die rede daarvoor is te vind in die feit dat die buite-tekstuele konteks van 1 Petrus binne die konteksbenadering nie net akkuraat gedefinieer is nie, maar ook in die interpretasie verreken is.
} 
watter tipe sosiale en politieke situasies van vandag deur die betrokke perikoop "belig" word.

\subsection{Implikasie vir onderrig en navorsing}

Hierbo (punt 2) is aangedui watter leemtes die agtergrondbenadering vir die akademiese kurrikulum en vir kommentaar-skrywe het. Hierdie leemtes kan op die volgende wyses uitgeskakel word:

- In die akademiese kurrikulum moet ná die feitekennis oor die eerste eeuse samelewings die eintlike saak aan die orde kom: om die student te begelei om raak te sien hoe die betrokke Bybelboek sou kon inpas binne 'n konstruksie van die leefwêreld van die tyd van sy ontstaan, en: watter effek dit het op die interpretasie van onderdele van die boek. Dit behoort ook vergestalting te vind in eksplisiete stappe in die eksegetiese proses met die oog op preekmaak $^{17}$.

- In kommentare (en die rapportering van alle interpretasiewerk) moet 'n duidelike konstruksie van die sosio-historiese konteks gemaak word, en die interpretasiewerk moet dan binne daardie konstruksie gedoen word.

\section{Literatuurverwysings}

Balch, D L 1981. Let wives be submissive: The domestic code in 1 Peter. Chicago: Scholars Press. (SBL Monograph Series, 26).

Barkhuizen J H, Stander H F, Swart G J (reds) 1992. Hupomnema. Feesbundel opgedra aan prof $J$ P Louw. Departement Grieks, Universiteit van Pretoria: Pretoria.

Barrett, C K (ed) 1980. Sparsa collecta: The collected essays of W C van Unnik (part 2). Leiden: Brill.

Beare, F W 1970 (3rd rev ed). The First Epistle of Peter. Oxford: Blackwell.

Botha, J 1990. Semeion. 'n Inleiding tot die interpretasie van die Griekse Nuwe Testament. Pretoria: NG Kerkuitgewers.

Chevallier, M-A 1974. Condition et vocation des Chreätiens en diaspora. Remarques exeägeätiques sur la 1 re Eptre de Pierre. RSR 48:387-398.

Crystal, David 1985. A dictionary of linguistics and phonenetics. Oxford: Basil Blackwell.

Deist, F E \& Burden J J 1980. ' $n$ ABC van Bybeluitleg, Pretoria: Van Schaik.

De Klerk B J \& Van Rensburg F J, 1998. Die geboorteproses van 'n preek. ' $n$ Handleiding vir Gereformeerde eksegese en prediking. Potchefstroom: Fakulteit Teologie, PU vir CHO.

Duvenage, $\mathrm{S}$ (s j). Die dékor van die Nuwe Testament. ' $n$ Kultuur-historiese agtergrondstudie. Pretoria: Interkerklike Uitgewerstrust.

17 De Klerk \& Van Rensburg (1998) het sodanige handleiding in konsepvorm beskikbaar gestel, en sedertdien in die onderrig gebruik. 
Elliott, J H 1981. A home for the homeless. A sociological exegesis of 1 Peter, its situation and strategy. Philadelphia: Fortress.

-, 1986. 1 Peter, its situation and strategy: a discussion with David Balch, in Talbert 1986:61-78.

Furnish, V 1975. Elect sojourners in Christ: an approach to the theology of First Peter. Perkins Journal 28:1-11.

Garrett, Susan R 1992. Sociology of early Christianity. Anchor Bible Dictionary, 6:89-99.

Goppelt, L 1978 (8th ed). Der erste Petrusbrief. Göttingen: Vandenhoeck \& Ruprecht.

Groenewald, E P 1977. Die briewe van Petrus; die brief van Judas. Kaapstad: NG Kerkuitgewers.

Kümmel, W G 1975. Introduction to the New Testament. Translated and edited by H C Kee. Nashville: Abingdon.

Lohse, E 1954. Paraënese und Kerygma im 1. Petrusbrief. ZNW 45:68-89.

Louw, J P \& Nida, E A 1988. Greek-English Lexicon of the New Testament based on semantic domains. Volumes I \& II. New York: United Bible Societies.

MacMullen, Ramsey 1981. Paganism in the Roman Empire. New Haven: Yale University Press.

Malherbe, A J 1983 (2nd enlarged ed). Social aspects of early Christianity. Philadelphia: Fortress Press.

-, 1986. Moral exhortation, A Greco-Roman sourcebook. Philadelphia: The Westminster Press.

Meeks, W A 1983. The first urban Christians; the social world of the apostle Paul. New Haven: Yale University Press.

Richard, E 1986. The functional Christology of First Peter, in: Talbert, C H (ed), 1986:121-139.

Selwyn, E G 1952 (2nd ed). The First Epistle of St Peter. London: Macmillan.

Talbert, C H (ed) 1986. Perspectives on First Peter. Macon, Georgia: Mercer University Press.

Van Rensburg, F J 1990. Indikatief en paraklese in 1 Petrus en die implikasie daarvan vir die kerklike prediking vandag. In die Skriflig 24: 71-101.

-, 1990b. The use of intersentence relational particles and asyndeton in First Peter. Neotest 24:283-300.

-, 1992b. The outline of First Peter - a reconsideration. Ekklesiastikos Pharos: 74/1 (NS3): 26-41.

-, 1993. 1 Petrus, in: Vosloo, W \& Van Rensburg, F J, 1993:1944-1958.

-, 1996. 'n Metodologiese verkenning na die verdiskontering van sosiohistoriese gegewens in die bestudering van vreemdelingskap in 1 Petrus. In die Skriflig 1996:37-55.

Van Rensburg, J J J 1992. Vreemdelingskap in 1 Petrus: Voorlopige definiëring van die betekenisse van die betrokke Griekse woorde, in: Barkhuizen $\mathbf{J} \mathrm{H}$, Stander $\mathrm{H}$ F \& Swart G J (reds), 1992:283-306.

Van Unnik, W C 1980. Corpus Hellenisticum Novi Testamenti, in: Barrett, C K (ed), 1908:194-214.

Van Wyk, G J \& Van Rensburg, F J 1997.'Oıќ́tal (huisbediendes) in die eerste eeuse Grieks-Romeinse samelewing. 'n Sosio-historiese konstruksie vir die interpretasie van 1 Petrus 2:18. In die Skriflig 1997:229-249. 
Vosloo, W \& Van Rensburg, F J 1993. Die Bybel in Praktyk. Vereeniging: Christelike Uitgewersmaatskappy.

Wilken, R L 1984. The Christians as the Romans saw them. New Haven: Yale University Press. 